\title{
Preoperative C-reactive protein levels to predict early and late mortalities after coronary artery bypass surgery: Eight years of follow-up
}

Albert H. M. van Straten, MD, ${ }^{a}$ Mohamed A. Soliman Hamad, MD, ${ }^{a}$ André J. van Zundert, MD, PhD,

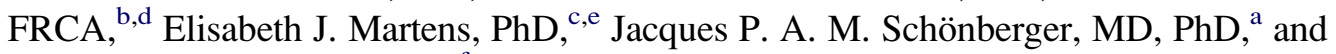
Andre M. de Wolf, MD, $\mathrm{PhD}^{\mathrm{f}}$

Objective: There is limited evidence that increased preoperative levels of C-reactive protein are associated with increased mortality after coronary artery bypass grafting. We retrospectively investigated in 5669 patients the predictive value of preoperative $\mathrm{C}$-reactive protein levels for early and late mortalities after coronary artery bypass grafting.

Methods: Patients undergoing isolated coronary artery bypass grafting between January 2000 and December $2007(\mathrm{n}=8500)$ were studied. Preoperative demographic data and risk factors and outcome data (mortality data) were prospectively collected in a database. Preoperative C-reactive protein levels were retrieved from the laboratory data.

Results: In 5669 of 8500 cases, the preoperative C-reactive protein level could be retrieved. Seventy-five patients were unavailable for follow-up. A preoperative C-reactive protein level greater than $10 \mathrm{mg} / \mathrm{L}$ was an independent risk factor for early mortality, whereas a level greater than $5 \mathrm{mg} / \mathrm{L}$ was a risk factor for late mortality. Other risk factors were age, sex, chronic obstructive pulmonary disease, diabetes, left ventricular ejection fraction less than $35 \%$, peripheral vascular disease, and previous cardiac surgery. We found a higher mean C-reactive protein value in patients with a left ventricular ejection fraction less than $35 \%(18.5 \pm 33 \mathrm{mg} / \mathrm{L})$ than in those with an ejection fraction greater than $35 \%(P<.0001)$.

Conclusions: Preoperative C-reactive protein levels can be used in risk stratification in coronary artery bypass grafting surgery. A C-reactive protein level greater than $10 \mathrm{mg} / \mathrm{L}$ is a risk factor for early mortality, whereas a level greater than $5 \mathrm{mg} / \mathrm{L}$ is a risk factor for late mortality.

Increased levels of C-reactive protein (CRP) are associated with increased incidences of coronary and cardiac events after percutaneous coronary intervention. ${ }^{1}$ For patients with chronic heart failure, CRP level is a major prognostic factor. $^{2}$

A few reports have addressed the correlations between elevated preoperative levels of CRP and early ${ }^{3}$ and late ${ }^{4}$ mortalities after coronary artery bypass grafting (CABG). In one study, a correlation was found between elevated CRP level and early graft occlusion. ${ }^{5}$ We investigated whether elevated preoperative CRP level is associated with

From the Departments of Cardio-Thoracic Surgery, ${ }^{\mathrm{a}}$ Anesthesiology, ${ }^{\mathrm{b}}$ and Education and Research, ${ }^{\mathrm{C}}$ Catharina Hospital-Brabant Medical School, Eindhoven, The Netherlands; the Department of Anesthesiology, University Hospital Ghent, ${ }^{\mathrm{d}}$ Ghent, Belgium; the Center of Research on Psychology in Somatic Diseases, Department of Medical Psychology, Tilburg University, ${ }^{\mathrm{e}}$ Tilburg, The Netherlands; and the Department of Anesthesiology, The Feinberg School of Medicine ${ }^{f}{ }^{\text {Northwestern }}$ University, Chicago, Ill.

Received for publication Dec 10, 2008; revisions received March 23, 2009; accepted for publication March 29, 2009; available ahead of print June 24, 2009.

Address for reprints: Mohamad A. Soliman Hamad, MD, Department of Cardiothoracic Surgery, Catharina Hospital, Michelangelolaan 2, Postbus 1350, 5602 ZA

Eindhoven, The Netherlands (E-mail: aasmsn@cze.nl).

J Thorac Cardiovasc Surg 2009;138:954-8

0022-5223/\$36.00

Copyright (c) 2009 by The American Association for Thoracic Surgery

doi:10.1016/j.jtcvs.2009.03.050 higher early and late mortalities in a large patient population undergoing isolated $\mathrm{CABG}$.

\section{MATERIALS AND METHODS Patients}

This study analyzed the data of patients who underwent isolated CABG between January 2000 and December 2007 at a single center. Since 2000, we have been able to measure preoperative CRP levels at our hospital. Clinical data, including demographic characteristics and risk factors, were prospectively collected and placed in a database. Preoperative CRP levels were retrieved from the laboratory data bank. This study was performed with permission from the local medical ethics committee.

\section{Operative Techniques}

All patients received short-acting anesthetic drugs to facilitate early extubation. Extracorporeal circulation was performed with normothermic, nonpulsatile flow. Cold crystalloid cardioplegia (St Thomas' Hospital solution) or warm blood cardioplegia was used to induce and maintain cardioplegic arrest, according to the surgeon's preference. All patients undergoing $\mathrm{CABG}$ with the use of extracorporeal circulation received a low dose of aprotinin ( 2 million kallikrein inactivating unit during extracorporeal circulation, administered in the prime solution. Patients undergoing off-pump surgery did not receive any aprotinin.

\section{Preoperative CRP Levels}

Preoperative CRP levels were retrieved from the laboratory data bank. Values below $6 \mathrm{mg} / \mathrm{L}$ were reported as "CRP $<6$," making analysis of 


\section{Abbreviations and Acronyms \\ $\mathrm{CABG}=$ coronary artery bypass grafting \\ $\mathrm{COPD}=$ chronic obstructive pulmonary disease \\ $\mathrm{CRP}=\mathrm{C}$-reactive protein \\ $\mathrm{LVEF}=$ left ventricular ejection fraction \\ PVD = peripheral vascular disease}

$\mathrm{CRP}$ as a continuous variable difficult. We therefore converted a report of " $\mathrm{CRP}<6$ " into a value of 5 in all analyses looking at continuous CRP levels. For most analyses, patients were grouped into 4 groups according to CRP level: group 1, which included those with CRP levels less than $6 \mathrm{mg} / \mathrm{L}$; group 2, which included those with CRP levels between 6 and $10 \mathrm{mg} / \mathrm{L}$; group 3, which included those with CRP levels between 11 and $30 \mathrm{mg} / \mathrm{L}$; and group 4, which included those with CRP levels greater than $30 \mathrm{mg} / \mathrm{L}$. Group 5 was added to include patients with an unknown preoperative CRP level. Because in our laboratory a CRP value less than $6 \mathrm{mg} / \mathrm{L}$, reported as $5 \mathrm{mg} / \mathrm{L}$, is considered abnormal, $6 \mathrm{mg} / \mathrm{L}$ was used as a cutoff value in several analyses studying preoperative CRP levels as a dichotomous variable. We chose 3 arbitrary values to divide patients with abnormal CRP levels into different groups and to examine whether the degree of elevation of CRP is correlated with the prognosis. The value of $10 \mathrm{mg} / \mathrm{L}$ was used as a cutoff point in the study of Biancari and colleagues, ${ }^{3}$ and the value of 30 $\mathrm{mg} / \mathrm{L}$ was used by Milazzo and associates. ${ }^{6}$

\section{Follow-up}

Follow-up data concerning mortality were gathered from databases of health insurance companies. The data of $9 \%$ of the total patient group could initially not be retrieved from these databases. We therefore contacted the general practitioners by telephone for information on mortality data of those patients. For the remaining patients, we contacted the city authorities of the cities in which the patients lived at the time of the operation. Early mortality was defined as death from any cause within 30 postoperative days, whereas late mortality was defined as death from any cause later than 30 postoperative days.

\section{Statistical Analyses}

Discrete variables were compared with the $\chi^{2}$ test and are presented as numbers and percentages. Continuous variables were compared with analysis of variance and $t$ test and are presented as mean \pm SD. Univariate and multivariate logistic regression analyses and Cox proportional hazard regression analyses (entry procedure) were performed to investigate the impact of biomedical variables on early and late mortalities, respectively. Comparison of long-term survival between the different groups was performed with the Wilcoxon-Gehan test. Univariate analyses were used to test for the potentially confounding effects of biomedical and demographic factors on outcome. If significant at $P<.05$, confounders were included in the multivariable regression analyses. The cumulative incidences of death in CRP groups were estimated according to the Kaplan-Meier method, comparing differences between groups with the log-rank test. The zero time point indicates the time of CABG. Hazard ratios with $95 \%$ confidence intervals are reported. All statistical analyses were performed with SPPS software (Statistical Product and Services Solutions, version 15.0; SPSS Inc, Chicago, Ill).

\section{RESULTS}

Between January 2000 and December 2007, a total of 8500 patients underwent isolated CABG in our center. In 5669 cases, a preoperative CRP level could be retrieved from the laboratory data bank. Of the 8500 patients, follow-up data was incomplete for 75 , resulting ultimately in
5625 patients with both a measured preoperative CRP level and a complete follow-up. Mean follow-up was $1394 \pm 858$ days, with a median of 1373 days. Demographic and clinical data stratified according to preoperative CRP group are listed in Table 1. Patients with elevated CRP levels were more often older and female and more frequently had chronic obstructive pulmonary disease (COPD), poor left ventricular ejection fraction (LVEF), peripheral vascular disease (PVD), low creatinine clearance, and a history of preoperative myocardial infarction.

Early and late mortalities stratified according to preoperative CRP level are shown in Table 2. Early mortality increased with increasing preoperative CRP level. For early mortality, the difference between groups 1 and 2 was not significant $(P=.408)$; all other between-group comparisons were significant $(P<.05$ for all). For late mortality, only the differences between group 1 and groups 2, 3, and 4 were statistically significant. The late mortality in group 5 was high. Most of the missing preoperative CRP values were those of patients included in the early phase of the study.

In Table 3, we show the survivals of each group after 1 and 5 years. With regard to 5 -year survival, all differences between groups were statistically significant except for those between groups 2 and 5 and between group 3 and 5 .

Univariate logistic regression analyses revealed preoperative CRP level as a risk factor for early mortality both as a continuous variable and as a dichotomous variable with a cutoff value of $6 \mathrm{mg} / \mathrm{L}$ (Table 4). Other patient-related risk factors that were identified included age, COPD, diabetes, LVEF less than $35 \%$, PVD, low creatinine clearance, previous cardiac surgery, and emergency operations. Sex, hypertension, and the use of extracorporeal circulation were not found to be risk factors for early mortality. Complications, such as perioperative myocardial infarction, perioperative use of intra-aortic balloon pump, and reexploration, were also identified as risk factors for early mortality.

All preoperative risk factors that were identified with univariate logistic regression analyses were entered into the multivariate logistic regression model. Preoperative CRP level as a continuous variable did prove to be an independent risk factor for early mortality. Other independent risk factors were age, COPD, diabetes, LVEF lower than $35 \%$, PVD, low creatinine clearance, and previous cardiac surgery. Emergency operation did not prove to be an independent risk factor. When the preoperative CRP level as a dichotomous parameter with a cutoff point of $6 \mathrm{mg} / \mathrm{L}$ was entered in a multivariate model using the same variables, it was also an independent risk factor.

Results of Cox regression analyses for risk factors of late mortality are shown in Table 5. Univariate analyses revealed preoperative CRP level as a risk factor for late mortality, both as a continuous variable and as a dichotomous variable with a cutoff value of $6 \mathrm{mg} / \mathrm{L}$. Furthermore, patient-related risk factors that were identified included age, sex, COPD, 
TABLE 1. Demographic and clinical data stratified according to preoperative C-reactive protein concentration

\begin{tabular}{|c|c|c|c|c|c|c|}
\hline & $\begin{array}{c}\text { Group 1 } \\
(\mathbf{n}=\mathbf{3 6 9 8})\end{array}$ & $\begin{array}{c}\text { Group } 2 \\
(\mathrm{n}=778)\end{array}$ & $\begin{array}{c}\text { Group 3 } \\
(\mathbf{n}=\mathbf{8 2 3})\end{array}$ & $\begin{array}{c}\text { Group } 4 \\
(\mathrm{n}=\mathbf{3 7 0})\end{array}$ & $\begin{array}{c}\text { Group 5 } \\
(n=\mathbf{2 8 3 1}) \\
\end{array}$ & $P$ value \\
\hline Age $(y$, mean \pm SD $)$ & $64.2 \pm 9.5$ & $64.6 \pm 9.6$ & $65.8 \pm 9.2$ & $66.9 \pm 8.7$ & $65.1 \pm 9.6$ & $<.0001$ \\
\hline Male (no.) & $2960(80.0 \%)$ & $586(75.3 \%)$ & $605(73.5 \%)$ & $278(75.1 \%)$ & $2130(75.2 \%)$ & $<.0001$ \\
\hline Hypertension (no.) & $1613(43.6 \%)$ & $361(46.4 \%)$ & $400(48.6 \%)$ & $172(46.5 \%)$ & $1189(42.0 \%)$ & .006 \\
\hline $\begin{array}{l}\text { Chronic obstructive pulmonary } \\
\text { disease (no.) }\end{array}$ & $402(10.9 \%)$ & $104(13.4 \%)$ & $140(17.0 \%)$ & $62(16.8 \%)$ & $365(12.9 \%)$ & $<.0001$ \\
\hline Diabetes (no.) & $785(21.2 \%)$ & $180(23.1 \%)$ & $199(24.2 \%)$ & $84(22.7 \%)$ & $615(21.7 \%)$ & .359 \\
\hline $\begin{array}{l}\text { Left ventricular } \\
\quad \text { ejection fraction }<35 \% \text { (no.) }\end{array}$ & $81(2.3 \%)$ & $29(3.8 \%)$ & $34(4.3 \%)$ & $24(6.7 \%)$ & $113(4.2 \%)$ & $<.0001$ \\
\hline $\begin{array}{l}\text { Peripheral vascular } \\
\text { disease (no.) }\end{array}$ & $382(10.3 \%)$ & $98(12.6 \%)$ & $133(16.2 \%)$ & $64(17.3 \%)$ & $320(11.3 \%)$ & $<.0001$ \\
\hline $\begin{array}{l}\text { Creatinine clearance } \\
\quad(\mathrm{mL} / \mathrm{min}, \text { mean } \pm \mathrm{SD})\end{array}$ & $75.5 \pm 25.4$ & $75.3 \pm 27.6$ & $73.6 \pm 29.7$ & $70.9 \pm 30.3$ & $72.3 \pm 26.8$ & $<.0001$ \\
\hline $\begin{array}{l}\text { Preoperative myocardial } \\
\text { infarction (no.) }\end{array}$ & $1402(38.3 \%)$ & $328(42.9 \%)$ & $369(45.4 \%)$ & $186(51.4 \%)$ & $1247(44.8 \%)$ & $<.0001$ \\
\hline $\begin{array}{l}\text { Previous coronary } \\
\text { artery bypass grafting (no.) }\end{array}$ & $174(4.7 \%)$ & $38(4.9 \%)$ & $32(3.9 \%)$ & $24(6.5 \%)$ & $166(5.9 \%)$ & .071 \\
\hline Off-pump surgery (no.) & $425(11.5 \%)$ & $95(12.2 \%)$ & $80(9.7 \%)$ & $39(10.5 \%)$ & $302(10.7 \%)$ & .435 \\
\hline Grafts placed (mean $\pm \mathrm{SD})$ & $3.4 \pm 1.1$ & $3.4 \pm 1.1$ & $3.5 \pm 1.0$ & $3.5 \pm 1.0$ & $3.3 \pm 1.1$ & $<.0001$ \\
\hline Emergency operation (no.) & $37(1.0 \%)$ & $10(1.3 \%)$ & $16(1.9 \%)$ & $16(4.3 \%)$ & $249(8.8 \%)$ & $<.0001$ \\
\hline $\begin{array}{l}\text { Perioperative myocardial } \\
\text { infarction (no.) }\end{array}$ & $87(2.4 \%)$ & $25(3.2 \%)$ & $22(2.7 \%)$ & $11(3.0 \%)$ & $91(3.2 \%)$ & .276 \\
\hline Reexploration (no.) & $161(4.4 \%)$ & $44(5.7 \%)$ & $43(5.2 \%)$ & $19(5.1 \%)$ & $156(5.5 \%)$ & .229 \\
\hline $\begin{array}{l}\text { Use of intra-aortic } \\
\text { balloon pump (no.) }\end{array}$ & $36(1.0 \%)$ & $10(1.3 \%)$ & $18(2.2 \%)$ & $14(3.8 \%)$ & $91(3.2 \%)$ & $<.0001$ \\
\hline
\end{tabular}

Group 1, C-reactive protein $<6 \mathrm{mg} / \mathrm{L}$; Group 2, C-reactive protein 6-10 mg/L; Group 3, C-reactive protein 11-30 mg/L; Group 4, C-reactive protein >30 mg/L; Group 5, C-reactive protein unknown.

diabetes, LVEF lower than $35 \%$, PVD, low creatinine clearance, history of preoperative myocardial infarction, previous cardiac surgery, number of grafts, use of extracorporeal circulation, emergency operation, and hypertension. Complications, such as perioperative myocardial infarction, perioperative use of intra-aortic balloon pump, and reexploration, were also identified as risk factors for late mortality.

All preoperative risk factors that were identified with univariate analyses were entered into the multivariate Cox regression model. Preoperative CRP level as a continuous variable was an independent risk factor for late mortality. Age, sex, COPD, diabetes, LVEF lower than 35\%, PVD, low creatinine clearance, history of preoperative myocardial infarction, previous cardiac surgery, and emergency operation were also independent predictors of late mortality.

TABLE 2. Early and late mortalities stratified according to preoperative C-reactive protein concentration

\begin{tabular}{lcc}
\hline \multicolumn{1}{c}{ C-reactive protein } & Early mortality & Late mortality \\
\hline$<6 \mathrm{mg} / \mathrm{L}($ group $1, \mathrm{n}=3698)$ & $52(1.4 \%)$ & $217(5.8 \%)$ \\
$6-10 \mathrm{mg} / \mathrm{L}($ group $2, \mathrm{n}=778)$ & $15(1.9 \%)$ & $80(10.1 \%)$ \\
$11-30 \mathrm{mg} / \mathrm{L}($ group $3, \mathrm{n}=823)$ & $33(4.3 \%)$ & $88(11.5 \%)$ \\
$>30 \mathrm{mg} / \mathrm{L}($ group $4, \mathrm{n}=370)$ & $27(7.2 \%)$ & $38(10.2 \%)$ \\
Unknown (group 5, $\mathrm{n}=2831)$ & $128(2.6 \%)$ & $747(15.5 \%)$ \\
$P$ value & $<.0001$ & $<.0001$ \\
\hline
\end{tabular}

Use of extracorporeal circulation and hypertension were not identified as independent risk factors. Preoperative CRP level also proved to be a risk factor when entered as a dichotomous parameter with a cutoff point of $6 \mathrm{mg} / \mathrm{L}$ in a multivariate model with the same variables.

Survival according to the Kaplan Meyer method stratified according to preoperative CRP level is plotted in Figure 1. Log-rank test showed the differences to be statistically significant (overall $P<.0001$ ). Differences observed between groups 1 through 4 were all significant (all $P<.05$ ), with the exception of the difference between groups 3 and $4(P=.151)$.

The relationship between LVEF and preoperative CRP level is shown in Table 6. Patients with impaired preoperative LVEF $(<35 \%)$ had higher preoperative CRP levels $(P=.0001)$.

TABLE 3. Survivals at 1 and 5 years stratified according to preoperative C-reactive protein concentration

\begin{tabular}{lcc}
\hline \multicolumn{1}{c}{ C-reactive protein } & 1-y survival & 5-y survival \\
\hline$<6 \mathrm{mg} / \mathrm{L}($ group $1, \mathrm{n}=3698)$ & $96.1 \% \pm 0.3 \%$ & $89.3 \% \pm 0.7 \%$ \\
$6-10 \mathrm{mg} / \mathrm{L}($ group $2, \mathrm{n}=778)$ & $93.7 \% \pm 0.9 \%$ & $84.5 \% \pm 1.7 \%$ \\
$11-30 \mathrm{mg} / \mathrm{L}($ group $3, \mathrm{n}=823)$ & $89.1 \% \pm 1.2 \%$ & $77.8 \% \pm 2.2 \%$ \\
$>30 \mathrm{mg} / \mathrm{L}$ (group 4, $\mathrm{n}=370)$ & $84.8 \% \pm 2.1 \%$ & $73.3 \% \pm 3.5 \%$ \\
Unknown (group 5, $\mathrm{n}=2831)$ & $92.5 \% \pm 0.4 \%$ & $84.0 \% \pm 0.6 \%$ \\
$P$ value & $<.0001$ & $<.0001$ \\
\hline
\end{tabular}


TABLE 4. Predictors of early mortality by univariate and multivariate logistic regression analyses

\begin{tabular}{|c|c|c|c|c|c|c|}
\hline \multirow[b]{2}{*}{ Risk factor } & \multicolumn{3}{|c|}{ Univariate } & \multicolumn{3}{|c|}{ Multivariate } \\
\hline & Hazard ratio & $\begin{array}{c}95 \% \text { Confidence } \\
\text { interval }\end{array}$ & $P$ value & Hazard ratio & $\begin{array}{c}5 \% \text { Confidence } \\
\text { interval }\end{array}$ & $P$ value \\
\hline Preoperative C-reactive protein* & 1.017 & $1.013-1.022$ & $<.0001$ & 1.013 & $1.007-1.019$ & $<.0001$ \\
\hline Age* & 1.082 & $1.065-1.099$ & $<.0001$ & 1.056 & $1.026-1.087$ & .001 \\
\hline Chronic obstructive pulmonary disease & 1.91 & $1.41-2.60$ & $<.0001$ & 1.67 & $1.05-2.64$ & .029 \\
\hline Diabetes & 1.48 & $1.12-1.96$ & .005 & 1.63 & $1.08-2.47$ & .020 \\
\hline Left ventricular ejection fraction $<35 \%$ & 6.02 & $4.18-8.68$ & $<.0001$ & 3.52 & $1.88-6.61$ & $<.0001$ \\
\hline Peripheral vascular disease & 1.60 & $1.15-2.23$ & .005 & 1.49 & $0.92-2.42$ & .102 \\
\hline Creatinine clearance* & 0.971 & $0.966-0.976$ & $<.0001$ & 0.980 & $0.971-0.990$ & $<.0001$ \\
\hline Previous coronary artery bypass grafting & 4.26 & $3.11-5.83$ & $<.0001$ & 2.98 & $1.64-5.41$ & $<.0001$ \\
\hline Emergency operation & 6.94 & $4.94-9.32$ & $<.0001$ & 2.32 & $0.89-5.99$ & .082 \\
\hline Perioperative myocardial infarction & 5.79 & $3.97-8.43$ & $<.0001$ & & & \\
\hline Reexploration & 5.78 & $4.27-7.82$ & $<.0001$ & & & \\
\hline Intra-aortic balloon pump & 14.96 & $10.52-20.52$ & $<.0001$ & & & \\
\hline Preoperative C-reactive protein $>5 \mathrm{mg} / \mathrm{L} \dagger$ & 2.86 & $2.00-4.10$ & $<.0001$ & 2.36 & $1.58-3.53$ & $<.0001$ \\
\hline Male & 0.77 & $0.58-1.02$ & .069 & & & \\
\hline Hypertension & 0.94 & $0.73-1.21$ & .659 & & & \\
\hline No. of grafts placed* & 0.912 & $0.817-1.017$ & .099 & & & \\
\hline Preoperative myocardial infarction & 1.12 & $0.92-1.37$ & .227 & & & \\
\hline
\end{tabular}

*Entered as a continuous variable. †Entered as a dichotomous variable with a cutoff point of $6 \mathrm{mg} / \mathrm{L}$ in a separate multivariate model from that used for C-reactive protein as a continuous variable.

\section{DISCUSSION}

In this study, it was confirmed that preoperative CRP level is an independent risk factor for early and late mortalities after CABG, as has been shown by others. ${ }^{3,4}$ CRP is an acute-phase protein, and elevated levels may be an indication of an underlying infectious disease or other inflammatory process. Every patient was investigated for underlying dis- ease before surgery. If any sign of infection was found, the operation was postponed unless the cardiac condition did not allow this. This is the reason that emergency operations were more frequent in the group of patients with a CRP level of more than $30 \mathrm{mg} / \mathrm{L}$ than in groups with lower CRP levels, as shown in Table 1. Thus we may assume that in elective cases no evident signs of infectious disease were present.

TABLE 5. Predictors of late mortality ( $>\mathbf{3 0}$ days after coronary artery bypass grafting): Univariate and multivariate Cox regression analyses

\begin{tabular}{|c|c|c|c|c|c|c|}
\hline \multirow[b]{2}{*}{ Risk factor } & \multicolumn{3}{|c|}{ Univariate } & \multicolumn{3}{|c|}{ Multivariate } \\
\hline & Hazard ratio & $\begin{array}{l}95 \% \text { Confidence } \\
\text { interval }\end{array}$ & $P$ value & Hazard ratio & $\begin{array}{l}95 \% \text { Confidence } \\
\text { interval }\end{array}$ & $P$ value \\
\hline Preoperative C-reactive protein* & 1.010 & $1.008-1.013$ & $<.0001$ & 1.007 & $1.004-1.010$ & $<.0001$ \\
\hline Age* & 1.090 & $1.082-1.097$ & $<.0001$ & 1.063 & $1.049-1.078$ & $<.0001$ \\
\hline Chronic obstructive pulmonary disease & 1.91 & $1.68-2.18$ & $<.0001$ & 1.70 & $1.42-2.07$ & $<.0001$ \\
\hline Diabetes & 1.68 & $1.49-1.88$ & $<.0001$ & 1.71 & $1.42-2.07$ & $<.0001$ \\
\hline Left ventricular ejection fraction $<35 \%$ & 3.16 & $2.61-3.81$ & $<.0001$ & 2.30 & $1.64-3.22$ & $<.0001$ \\
\hline Peripheral vascular disease & 2.14 & $1.88-2.45$ & $<.0001$ & 1.71 & $1.38-2.14$ & $<.0001$ \\
\hline Creatinine clearance* & 0.975 & $0.973-0.977$ & $<.0001$ & 0.986 & $0.982-0.992$ & $<.0001$ \\
\hline Preoperative myocardial infarction & 1.29 & $1.19-1.40$ & $<.0001$ & 1.18 & $1.03-1.35$ & .016 \\
\hline Previous coronary artery bypass grafting & 1.97 & $1.68-2.31$ & $<.0001$ & 1.92 & $1.42-2.61$ & $<.0001$ \\
\hline Off-pump surgery & 0.67 & $0.53-0.86$ & .001 & 1.19 & $0.83-1.72$ & .330 \\
\hline No. of grafts placed* & 1.055 & $1.009-1.104$ & .019 & 1.199 & $0.832-1.729$ & 677 \\
\hline Emergency operation & 2.09 & $1.73-2.53$ & $<.0001$ & 2.07 & $1.20-3.55$ & .01 \\
\hline Hypertension & 1.16 & $1.04-1.29$ & .004 & 1.07 & $0.90-1.29$ & .414 \\
\hline Perioperative myocardial infarction & 2.51 & $2.02-3.12$ & $<.0001$ & & & \\
\hline Reexploration & 2.07 & $1.74-2.45$ & $<.0001$ & & & \\
\hline Intra-aortic balloon pump & 3.77 & $3.07-4.63$ & $<.0001$ & & & \\
\hline Preoperative C-reactive protein $\dagger$ & 2.20 & $1.86-2.60$ & $<.0001$ & 1.79 & $1.50-2.14$ & $<.0001$ \\
\hline Male & 0.84 & $0.75-0.951$ & .005 & 1.28 & $1.03-1.58$ & .021 \\
\hline
\end{tabular}

*Entered as a continuous variable. $\dagger$ Entered as a dichotomous variable with a cutoff point of $6 \mathrm{mg} / \mathrm{L}$ in a separate multivariate model from that used for C-reactive protein as a continuous variable. 


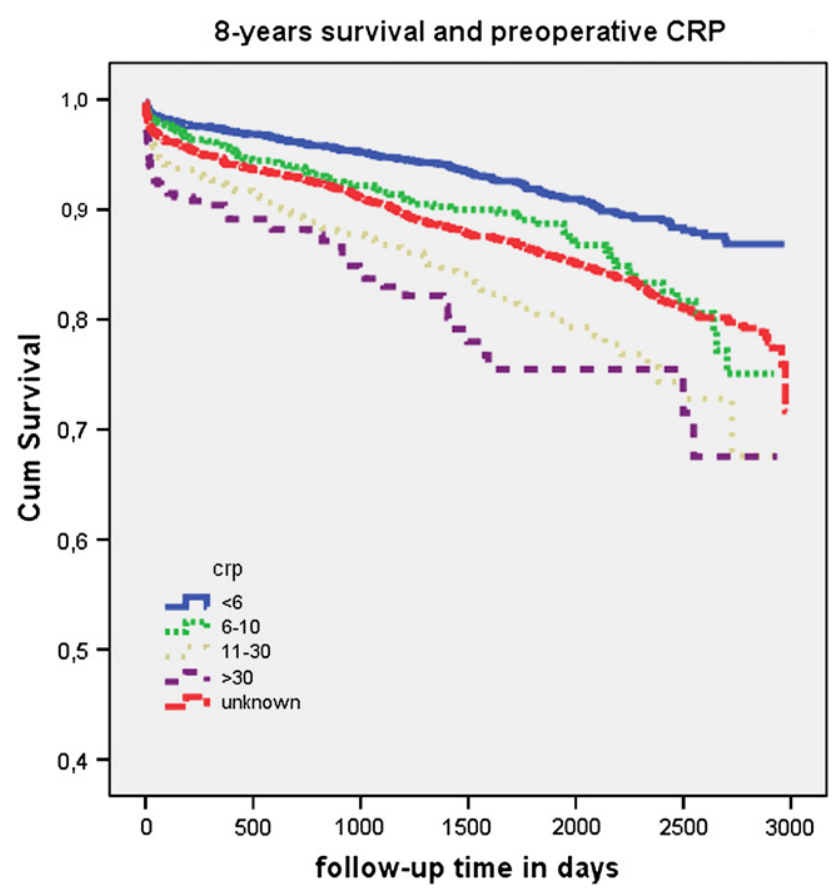

FIGURE 1. Survival stratified according to preoperative C-reactive protein $(C R P)$ concentration in milligrams per liter (Kaplan-Meier plots)

Elevated levels of CRP were still found in some patients. Only since 2004 have we routinely measured preoperative CRP in every case. We are therefore missing CRP values for patients who were operated on in the early years of the study. This explains why the group of patients with missing values had a higher risk for late mortality than did the groups with low CRP levels. Because these patients were operated on in the early portion of the experience, the follow-up period has been longer and thus the chance for late mortality higher. We still considered it worthwhile to include patients from this early period to clarify the impact of preoperative CRP levels on late mortality.

There was no difference in early mortality between groups 1 and 2. Further increases in preoperative CRP did increase the risk of early mortality. This suggests that a cutoff value of $10 \mathrm{mg} / \mathrm{L}$ is probably a good indicator for increased risk of early mortality. For late mortality, preoperative CRP level was an independent risk factor when it was used as a continuous variable indication, with risk increasing with CRP level. Importantly, log-rank test showed no difference between group groups 3 and 4 , indicating that a further increase in preoperative CRP beyond $30 \mathrm{mg} / \mathrm{L}$ does not further increase the risk of late mortality. It seems remarkable that even a small increase in preoperative CRP level $(6-10 \mathrm{mg} / \mathrm{L})$ proved to be a risk factor for late mortality. The predictive value of CRP for recurrent cardiovascular events and death has been established previously among patients with documented coronary artery disease. ${ }^{7}$ A recent study ${ }^{8}$ has shown
TABLE 6. Left ventricular ejection fraction and preoperative Creactive protein

\begin{tabular}{lcc}
\hline $\begin{array}{c}\text { Left ventricular } \\
\text { ejection fraction }\end{array}$ & $\begin{array}{c}\text { C-reactive protein } \\
(\mathbf{m g} / \mathbf{L}, \text { mean } \pm \text { SD) }\end{array}$ & No. of patients \\
\hline$>35 \%$ & $10.1 \pm 17$ & 6219 \\
$<35 \%$ & $18.5 \pm 33$ & 181 \\
$P$ value & $<.0001$. & \\
\hline
\end{tabular}

that patients with increased CRP level undergoing CABG have an increased long-term risk of cardiovascular events. This could explain the poorer long-term survival of these patients. Interestingly, elevated CRP levels were found in patients with a low LVEF, a finding confirmed by others. ${ }^{4,5}$

\section{Study Limitations}

First, this was not a prospective randomized study, which warrants caution in our conclusions. Second, in our institution a CRP level lower than $6 \mathrm{mg} / \mathrm{L}$ is reported only as " $<6 \mathrm{mg} / \mathrm{L}$," thus limiting the use of CRP level as a continuous variable as discussed previously. One of the most important limitations of this study is the number of missing CRP values in the early years. We tried to overcome this problem by using proper statistical tools.

\section{CONCLUSIONS}

In conclusion, preoperative CRP levels can be used in risk stratification in CABG, with a level greater than $10 \mathrm{mg} / \mathrm{L}$ as a risk factor for early mortality and a level greater than $5 \mathrm{mg}$ / $\mathrm{L}$ as a risk factor for late mortality. A prospective study might show whether postponing the operation could influence the prognosis for this group of patients.

\section{References}

1. Bassuk SS, Rifai N, Ridker PM. High-sensitivity C-reactive protein: clinical importance. Curr Probl Cardiol. 2004;29:439-93.

2. Yin WH, Chen JW, Jen HL, Chiang MC, Huang WP, Feng AN, et al. Independent prognostic value of elevated high-sensitivity C-reactive protein in chronic heart failure. Am Heart J. 2004;147:931-8.

3. Biancari F, Lahtinen J, Lepojärvi S, Rainio P, Salmela E, Pokela R, et al. Preoperative C-reactive protein and outcome after coronary artery bypass surgery. Ann Thorac Surg. 2003;76:2007-12.

4. Kangasniemi OP, Biancari F, Luukkonen J, Vuorisalo S, Satta J, Pokela R, et al. Preoperative C-reactive protein is predictive of long-term outcome after coronary artery bypass surgery. Eur J Cardiothorac Surg. 2006;29:983-5.

5. Hedman A, Larsson PT, Alam M, Wallen NH, Nordlander R, Samad BA. CRP, IL6 and endothelin-1 levels in patients undergoing coronary artery bypass grafting. Do preoperative inflammatory parameters predict early graft occlusion and late cardiovascular events? Int J Cardiol. 2007;120:108-14.

6. Milazzo D, Biasucci LM, Luciani N, Martinelli L, Canosa C, Schiavello R, et al. Elevated levels of $\mathrm{C}$-reactive protein before coronary artery bypass grafting predict recurrence of ischemic events. Am J Cardiol. 1999;84:459-61, A9.

7. Zebrack JS, Muhlestein JB, Horne BD, Anderson JL. Intermountain Heart Collaboration Study Group. C-reactive protein and angiographic coronary artery disease: independent and additive predictors of risk in subjects with angina. J Am Coll Cardiol. 2002;39:632-7.

8. van der Harst P, Voors AA, Volbeda M, Buikema H, van Veldhuisen DJ, van Gilst WH. Usefulness of preoperative C-reactive protein and soluble intercellular adhesion molecule-1 level for predicting future cardiovascular events after coronary artery bypass grafting. Am J Cardiol. 2006;97:1697-701. 